\title{
EFFECTS OF HYDROPHILIC SILICA NANOPARTICLES ON MORPHOLOGY AND MECHANICAL PROPERTIES OF A TYPICAL TYRE COMPOUND
}

\author{
Narjes Dortaj ${ }^{1}$, Ali Mohebbi ${ }^{1}{ }^{凶}$, Hamidreza Bagheri ${ }^{1}$, Majid Aman-Alikhani ${ }^{2}$, \\ Maryamossadat Rohani Yazdi ${ }^{3}$
}

https://doi.org/10.23939/chcht16.01.150

\begin{abstract}
This research aimed to study the effects of adding hydrophilic silica nanoparticles as nanofiller on tread properties of a typical tyre compound. In this respect, four compounds were prepared as a representative of the tread of the tyre. The amount of $0,1,3$, and $5 \mathrm{phr}$ (parts of filler per hundred parts of rubber) of nanofiller were added by melt mixing method. Physical and mechanical properties of compounds were measured. The structure and morphology of the fractured surface of the compounds were characterized using field emission scanning electron microscopy (Fe-SEM). The results of cure and mechanical analysis of the compound series showed that the sample containing $3 \mathrm{phr}$ of nanofiller possesses better properties. This observation is due to higher interaction between nanofiller and polymer macromolecules that causes better dispersion of the nanoparticles in polymer matrix.
\end{abstract}

Keywords: rubber filler, mechanical properties, hydrophilic silica nanoparticles, melt mixing method, abrasion resistance.

\section{Introduction}

Tyre, as the last rotating member of vehicles, plays an important role in vehicle control. Therefore, selection of tyre and its maintenance are important factors for the better performance of the system. ${ }^{1}$ Besides, the need to conserve fuel in motor vehicles dictates the use of new materials in tyres. The growing demand for increased fuel efficiency and rising standards of safety, durability and noise for tyres, as represented by the new EU tyre label, the tyre manufacturers continually try to improve the

\footnotetext{
${ }^{1}$ Department of Chemical Engineering, Faculty of Engineering, Shahid Bahonar University of Kerman, Kerman, Iran

${ }^{2}$ Compound Development Manager, Barez Tyre Co., Kerman, Iran

${ }^{3}$ Golnaz Vegetable Oil Co.

amohebbi2002@yahoo.com,amohebbi@uk.ac.ir

(C) Dortaj, N.; Mohebbi, A.; Bagheri, H.; Aman-Alikhani, M.; Yazdi, M.R., 2022
}

quality and biocompatibility of their products. ${ }^{2,3}$ Rubber, as the base polymer of tyre, is usually reinforced with fillers to enhance its properties. Conventional reinforcing fillers in rubber compounds are carbon black and silica. New innovations in the field of nanomaterials provide production of new fillers (nanofillers) that pave the path to the "quality triple triangle", including safety, durability and noise pollution, as much as possible..$^{4-6}$ Nanoparticles have attracted much attention due to their unique properties like very low size, high surface area and surface activity. Such nano fillers are used in rubber formulations in order to improve the physical and mechanical properties. $^{7-9}$ Nano fillers have indicated a great potential to improve tyres properties. Compared to conventional filler, the high interfacial surface area of nanofillers lessen the quantity of filler required and thus reduces the specific gravity of the compound and heat generation that ultimately lead to the high performance of tyre and its better fuel efficiency. ${ }^{10-13}$ Silica is one of the promising environment friendly and inexpensive reinforcing filler, which can be prepared from renewable resources. Among different inorganic fillers, nanosilica stands out as it provides significant improvement in thermal, mechanical and dynamic properties of elastomers. Silica also plays an important role as a promising surrogate for carbon black, which reduce the environmental pollution, as well as nonrenewable energy source. One of the major problems for the rubber compound is the weak distribution of filler in the polymer matrix. This problem is more imperative for silica filler due to its surface polarity. To improve the distribution of silica filler in the polymer matrix, surface modification is required. ${ }^{14-17}$ When added to rubber it slows down the cure rate and consequently reduces the crosslink density. Surface modification of silica such as grafting polymer chains, polymer coating, addition of silane coupling agent, mechano-chemical method and so on is necessary to improve the interaction of silica with polymeric materials and to get homogeneous dispersion inside the matrix. One of the major problems for the rubber compound is the weak distribution of filler in the 
polymer matrix. This problem is more imperative for silica filler due to its surface polarity. To improve the distribution of silica filler in the polymer matrix, surface modification is required. The particle size of filler and surface functionality are two important factors that considerably influence the reinforcement effects of filler. As reducing the size of filler leads to improvement of its surface area, silica nanoparticles with an extremely large surface area are aimed to have significant influences on the cure and mechanical properties of tyre compound. ${ }^{18-20}$ The linkage between nanoparticles and rubber compounds, which occurs at the atomic scale, improves physical and mechanical properties of the rubber, e.g., increasing abrasion resistance and tensile strength of tyre, improving its thermal properties, as well as increasing tensile fractures and appearance of rubber. All these enhanced properties of tyre will create a product with excellent quality as well as good-looking and marketable that is competitive in global markets. ${ }^{21,22}$

Because of the importance of fillers in the rubber industry, many researchers have attempted to investigate this issue. Park et al. ${ }^{23}$ studied the effect of thermal treatment on the properties of nanosilica/rubber compound. They checked the crosslink density and tearing energy of compound to determine its mechanical interfacial properties. Their results revealed that thermal treatment that improves dispersion of silica in rubber matrix increases the siloxane bond on the silica surface and thus improves the tearing energy of compound. Chen et $a .^{24}$ investigated the reinforcement effects of nanosilica on natural rubber (NR) based nanocomposite. The selfassembly method was used to produce NR/nanosilica nanocomposite. Measuring thermal, mechanical and morphology properties of the nanocomposite indicated that homogenous dispersion of silica nanoparticles significantly increases thermal resistance and storage modulus of NR host. Mathew and Narayanankutty ${ }^{25}$ synthesized nanoscale silica by acid hydrolysis of sodium silicate using dilute hydrochloric acid under controlled conditions. They investigated mechanical properties of natural rubber/Nylon-6 short fiber hybrid composite filled by the synthesized nanosilica as reinforcing filler. Their achievements were improvement of tensile strength, modulus, tear strength, abrasion loss, and hardness of nanocomposite. Moreover, resilience and compression set were adversely affected. Meera $e t a l .^{26}$ studied the stress relaxation behavior of the composites of natural rubber were filled with $\mathrm{TiO}_{2}$ and nanosilica, with reference to the filler loading and strain level. They observed that the rate of stress relaxation increases with increase in filler loading, which is higher for silica-filled NR compared to $\mathrm{TiO}_{2}$-filled NR. They also investigated the effect of ageing on the stress decay and found that the rate of stress relaxation decreased after ageing. Their experimental data were fitted with the stretched Kohlrausch equation. ${ }^{26}$ Eventually, they estimated the relaxation time and the stretching exponent in order to understand the mechanism of the relaxation processes in the filled natural rubber composites, from the fitting parameters. Chayan and Bharat $^{27}$ prepared silica-nitrile rubber nanocomposites, in which the surface of silica nanoparticles was modified. Increasing in tensile strength, elongation at break and thermal stability of the modified silica nanocomposite were observed compared to composites containing the silica particles without surface modification. Nurul Hayati Yusof et $a l .^{28}$ prepared natural rubber with filler nanomatrix by forming a chemical linkage between NR and filler nanoparticles. The filler nanomatrix structure was formed by graft copolymerization of vinyltriethoxysilane onto natural rubber particles. The silica nanoparticles were produced during the graft copolymerization through hydrolysis and condensation, i.e., sol-gel reaction. They studied mechanical properties of nanocomposites and observed that tensile properties, loss modulus and loss tangent of the nanocomposite improved significantly. Jaleel Kareem et al. ${ }^{29}$ studied the effect of nano silica as a filler with loading level (i.e., 0.1, $0.3,0.5,1,3,5,10,20,30$, and 40 parts of filler per hundred parts of rubber (phr)) on mechanical properties of styrene-butadiene rubber (SBR). Their results showed that small quantities of silica nanoparticles improved the mechanical properties better than high quantities. This result was due to the fact that silica at low concentration acts as a filler in SBR composite and at high levels nanoparticles aggregate with an irregular distribution in the rubber matrix, which reduces their properties. They also concluded that the optimum percent of silica nanoparticles was $1 \mathrm{phr}$, which gives a better performance for tensile strength, tear resistance, fatigue resistance, and abrasion loss.

Although, due to multiple properties of the silica nanoparticles, they have been used in most industries like the construction industry, production of concrete, cement industry and so on, and almost many researchers have studied in the field of composites reinforced with nanoparticles as fillers. Nanofillers are playing an increasingly important role in the field of rubbers. They can be dispersed as individual particles in the polymer matrix, with at least one dimension at the nanoscale. In this study, our novelty is case study, where for the first time we used the hydrophilic silica nanoparticles to improve mechanical properties of a typical tyre compound that is produced in Barez tyre company. All tests of this research were carried out on a real compound according to industry standards in the research laboratory of Barez Tyre Co., Kerman, Iran. In this study, hydrophilic silica nanoparticles were used as a filler in tread compound of tyre. The aim of this study was to increase the abrasion 
resistance of the tyre in order to increase its life. The positive and negative effects of this filler on the other mechanical properties of the tyre were also investigated. It is expected the achievements can be extended to the industrial scale.

\section{Experimental}

\subsection{Materials}

The raw material used in this study were SBR 1712 (Bandar Imam Petrochemical Company Ltd. Mahshahr, Iran), carbon black N339 (Doodeh Sanati Pars Company, Tehran, Iran), aromatic oil (Behran Oil Company, Tehran, Iran), stearic acid (Orient Containers Sdn Bhd, Malaysia), microcrystalline wax (Rose Polymer Co.,Ltd, Tehran, Iran), zinc oxide (Roy Gostar Jam, Tehran, Iran), 6PPD (N-(1,3-dimethylbutyl)-N'-phenyl-p-phenylenediamine) and TMQ (2,2,4-trimethyl-1,2-dihydroquinoline scored off). The last two materials were purchased from Shanghai Ruizheng Chemical Technology Co., Ltd. Shanghai, China, and were used as protective agents. Hydrophilic silica nanoparticles were purchased from Nano Rahpouyan Mahan Co., Iran. Sulfur and TBBS ( $N$ tert-butyl-2-benzothiazole sulfenamide) were used. TBBS was as an accelerator. Specifications of silica nanoparticles provided by the supplier are given in Table 1 .

Table 1. Characterization of silica nanoparticles

\begin{tabular}{|c|c|}
\hline Details & Silicon oxide $\left(\mathrm{SiO}_{2}\right)$ \\
\hline Purity & $99+\%$ \\
\hline ASP $^{1}$ & $20-30 \mathrm{~nm}$ \\
\hline $\mathrm{SSA}^{2}$ & $180-600 \mathrm{~m}^{2} / \mathrm{g}$ \\
\hline Color & white \\
\hline Bulk density & $<0.01 \mathrm{~g} / \mathrm{cm}^{3}$ \\
\hline True density & $2.4 \mathrm{~g} / \mathrm{cm}^{3}$ \\
\hline
\end{tabular}

Notes: ${ }^{1}$ average size of particles; ${ }^{2}$ specific surface area; * bulk density, also called apparent density or volumetric density, is a property of powders, granules, and other divided solids. One of the parameters specified in the company's catalog as specifications for nanosilica.

\subsection{Processing of Nanocomposites}

Four compounds were prepared. The first one, without nanofiller, was used as a reference and the properties of other compounds were compared with it. To the compounds 2, 3 and 4 a nanofiller in amount of 1, 3 and $5 \mathrm{phr}$, respectively, was added. The mixing operation, physical and mechanical tests were performed in the research laboratory of Barez Tyre Co., Kerman, Iran. Compound mixing was performed by melt mixing method in two steps (melt mixing is a high-temperature process requiring high-shear mixers or extruders and temperatures above the melting point or the glass transition point of the polymer). The first step was the production of masterbatch (uncured rubber and additives), consequently uncured rubber and chemicals were mixed in 21 laboratory banbury mixer with tangential rotors in $40 \mathrm{~s}$. Next, carbon black was added to the mixer and then continuously mixed for $60 \mathrm{~s}$. Then, to produce the masterbatch, by adding oil to the mixture, three stages of mixing were done. Each stage lasted 50 seconds under the ram pressure. After cooling the master-batch in water and conditioned at $296 \pm 2 \mathrm{~K}$ for $2-3 \mathrm{~h}$, final-batch by adding the accelerator and sulfur was prepared. The nanofiller was added to compounds 2,3 and 4 during preparation of the master-batch with other chemicals. Tables 2 and 3 give formulation of the master and final-batch of the nanocomposite series under this study, they were named $\mathrm{T}$ group. After final mixing and $24 \mathrm{~h}$ maturation, the curing process was performed by a lab curing press at $433 \mathrm{~K}$ for $20 \mathrm{~min}$.

Table 2. Formulation of the master-batch of $\mathrm{T}$ compounds (g)

\begin{tabular}{|c|c|c|c|c|}
\hline Component & $\begin{array}{c}\text { MT- } \\
1\end{array}$ & MT-2 & MT-3 & MT-4 \\
\hline SBR 1712 & 696 & 693 & 688 & 682 \\
\hline CB N339 & 405.1 & 403.4 & 400.0 & 396.7 \\
\hline Aromatic oil & 50.6 & 50.4 & 50.0 & 49.6 \\
\hline Stearic acid & 10.1 & 10.1 & 10.1 & 9.9 \\
\hline 6PPD & 10.1 & 10.1 & 10.1 & 9.9 \\
\hline TMQ & 5.1 & 5.0 & 5.0 & 5.0 \\
\hline Microcrystalline wax & 7.6 & 7.6 & 7.5 & 7.4 \\
\hline $\mathrm{ZnO}$ & 15.2 & 15.1 & 15.0 & 14.9 \\
\hline Hydrophilic nanoSiO $_{2}$ & - & 5.0 & 15.0 & 24.8 \\
\hline
\end{tabular}

Table 3. Formulation of the final-batch of $\mathrm{T}$ compound $(\mathrm{g})$

\begin{tabular}{|c|c|c|c|c|}
\hline Component & T-1 & T-2 & T-3 & T-4 \\
\hline MT-1 & 986 & - & - & - \\
\hline MT-2 & - & 986 & - & - \\
\hline MT-3 & - & - & 986 & - \\
\hline MT-4 & - & - & - & 985.7 \\
\hline TBBS & 6.2 & 6.2 & 6.2 & 6.1 \\
\hline Sulfur & 8.3 & 8.3 & 8.2 & 8.1 \\
\hline
\end{tabular}

Natural rubber (NR) having viscosity (ML1+4@373 K) of $70 \pm 2$ with density $0.94 \mathrm{~g} / \mathrm{cm}^{3}$, was purchased from RRII, Kottayam. Nanosilica with surface area of $575 \mathrm{~m}^{2} / \mathrm{g}$ and modified nanosilica were prepared in our laboratory. In the first stage (master-batch production), after $40 \mathrm{~s}$ of mixing uncured rubber and chemicals, the temperature was adjusted at $341 \mathrm{~K}$. After adding carbon black, the temperature increased to $373 \mathrm{~K}$. When the oil was added, the temperature decreased, however, after complete mixing, the temperature increased. After cooling the master-batch with water bath 
and conditioned at $296 \pm 2 \mathrm{~K}$ for $2-3 \mathrm{~h}$, final batch by adding the accelerator and sulfur was prepared in four steps, $40 \mathrm{~s}$ each. At the end of the process the final batch temperature was $353 \mathrm{~K}$. The nanofillers were added to compounds 2, 3 and 4 during preparation of the masterbatch with other chemicals at the beginning of the process. Also, speed of rotor for master-batch and final-batch was 80 and $50 \mathrm{rpm}$, respectively and the average fill factor was $70 \%$.

\subsection{Characterization}

The cure characteristics of the compounds such as Mooney viscosity and rheometer were determined using MOONEY MV 2000 as per ASTM-D1646 and RHEOMETER MDR 2000 as per ASTM-D2084, respectively, both from ALPHA TECHNOLOGIES, USA. The output parameters of rheometer are $T_{10}$, process safety of a compound in high-temperature in the production line, $\mathrm{T}_{40}$, half-time curing compound and $\mathrm{T}_{90}$ time to get $90 \%$ cure. The structural property of nanocomposites was obtained using field emission scanning electron microscopy (Fe-SEM) analysis. The prepared nanocomposite specimens were sliced in liquid nitrogen temperature. The cross sections were supported by gold mesh grids. Samples were analyzed using HITACHIS-4160 Fe-SEM with a $30 \mathrm{kV}$ operating voltage, Japan.

\subsection{Mechanical Properties}

The tensile strength values such as tensile stressstain, elongation at break and modulus of ring samples were measured as according to ASTM-D1414 using Zwick/ROELL Germany testing machine. The test speed was $500 \mathrm{~mm} / \mathrm{min}$. The hardness of the samples was examined with a Shore-A durometer as per ASTM-D2240 (Zwick/ROELL Germany). Specific gravity value of the samples was measured according to Archimedes law using Zwick/ROELL Germany testing machine. Resilience was the next property of the samples that was measured, according to ASTM-D7121, Zwick/ROELL Germany. Abrasion resistance was estimated according to ASTM-D5963 and ISO-53516 using Pico abrasion tester from FERRY industries USA. Heat buildup (HBU) of the cylindrical samples with an initial height of $25 \mathrm{~mm}$, was examined using Toyo Seiki Seisaku-Sho, Ltd, Japan according to ASTM-D623 with the frequency of $30 \mathrm{~Hz}$. Flex cracking resistance of the samples was estimated using Demattia type flex cracking tester according to ASTM-D813, Toyo Seiki Seisaku-Sho Ltd, Japan. The dispersion of nanofiller in rubber matrix was measured by dispers grader 100, Sweden according to ASTM-D2663 and ISO-11345.

\section{Results and Discussion}

\subsection{Cure Characteristics}

Mooney viscosity represents compound processability in production line. Fig. 1 demonstrates the Mooney viscosity of the nanocomposites. It can be observed that by increasing the concentration of silica nanoparticles, the viscosity decreases from 50 to $47 \mathrm{MU}$. This result is due to better reinforcement effect of nanoparticles on polymer matrix because of their good dispersion in the base rubber. Both better dispersion of filler in rubber and higher shearing stresses by the incorporation of nanoparticles are the reasons of viscosity decrease. But at higher temperature dispersion of filler in rubber has dominate effect. ${ }^{30}$ Mooney viscosity represents compound processability in the production line. The higher value of this property indicates the higher resistance of the compound against the rotor rotation of the device that shows the lower compound processability. Based on the results, it can be observed that by increasing the concentration of silica nanoparticles, the viscosity decreases. MDR rheometer test results are provided in Table 4. According to the definition of $\mathrm{T}_{10}$, the greater value of this parameter is less sensitive to scorch. Since the combination of $\mathrm{T}_{40}$ and $\mathrm{T}_{90}$ shows cure conditions and the objective is an economic justification of the cure reaction in the shortest time possible, the nanocomposite with $3 \mathrm{phr}$ filler is the desired option. According to obtained experimental data, adding nanofiller has improved rubber properties. However, the value of nanosilica phr should be in the range of 1-3. Referring to Dileep and Narayanankutty ${ }^{31,32}$ higher values of phr due to hydrophilic nature of silica particles lead to formation of aggregates and when $\mathrm{phr}>5$ only a marginal improvement is observed.

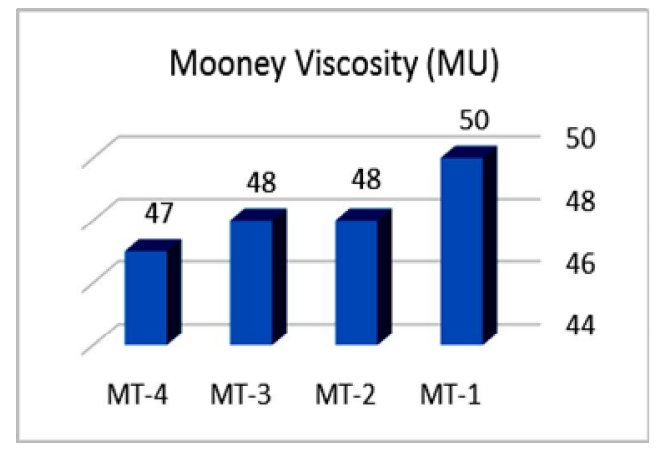

Fig. 1. Mooney viscosity of nanocomposite series 
Table 4. MDR rheometer test results of nanocomposites series

\begin{tabular}{|c|c|c|c|}
\hline Nano-silica, $\mathrm{phr}$ & $\mathrm{T}_{10}, \min$ & $\mathrm{T}_{40}, \min$ & $\mathrm{T}_{90}, \min$ \\
\hline 0 & 2.77 & 4.05 & 9.65 \\
\hline 1 & 3.14 & 4.48 & 9.59 \\
\hline 3 & 3.19 & 4.37 & 9.65 \\
\hline 5 & 3.10 & 4.63 & 10.58 \\
\hline
\end{tabular}

The knowledge of rheological and processing characteristics of rubber-based nanocomposites plays a vital role in determining the design and subsequent fabrication aspects of any finished product. Therefore, it is of great interest to investigate the rheological and processing behavior of rubber-based nanocomposites. ${ }^{30}$ Carbon black has important effect on rubber rheological characteristics and its modification by nanofiller improve physical and mechanical properties of rubber. Indeed, modification of carbon black leads to increased particle accumulation on surface rubber and increased rubber surface activity. The effect of fillers on rubber reinforcement depends on the filler properties, e.g., particle size, shape and aspect ratio, dispersion of filler in the polymer matrix, and interaction with polymer. Because of small particle size and complex aggregate structure of precipitated silica, it imparts the highest degree of reinforcement to rubber among all of the nonblack particulate fillers. Nanofillers, which range from 1 to $100 \mathrm{~nm}$, are able to significantly improve the mechanical performance of the rubber products and provide good reinforcement. The high surface area of nanoparticles leads to more polymer chains attached to the surface. This restricts the movement of polymer chains under loading, resulting in high reinforcement. Therefore, nanoparticles are profoundly important to the reinforcement of elastomers. Adding small quantities of silica nanoparticles, as compared to high quantities, improved the mechanical properties, which is due to the fact that silica at low concentration acts as a filler to fill the spaces in the recipe of SBR composite. At high quantities, nanoparticles act as microparticles and aggregate between chains with irregular distribution in rubber matrix, consequently this fact reduces the properties. This finding is in accordance with reference ${ }^{25}$ used in the paper.

\subsection{Mechanical Properties}

Table 5 gives the effect of silica nanoparticles on tensile properties of rubber. Based on the definition of tensile stress-stain, modulus and elongation at break, the greatest value of these parameters is more favorable. According to the data in Table 5, nanocomposite with $3 \mathrm{phr}$ nanofiller has the maximum tensile and modulus (i.e. $15.90 \mathrm{MPa}, 11.70 \mathrm{MPa}$ ). The maximum elongation at break is for $1 \mathrm{phr}$ silica nanoparticles. Referring to Meera et $a l .^{26}$ we can conclude, there is a good dispersion of filler and strong interactions between filler particles and rubber according to these tests. Improved tensile strength caused by good dispersion of nanofiller in rubber and higher interactions between them lead to better stress transfer from the matrix polymer to the filler particles. This strong interaction limits the mobility of the filler nanoparticles, which decreases the elongation and increases the modulus. Therefore, according to this test, the nanocomposite with $3 \mathrm{phr}$ nanofiller is the acceptable option. This finding is in accordance with that reported by Ahmed et al. ${ }^{29}$ The tensile strength in the sample with $5 \mathrm{phr}$ nanofiller decreased to 13.6. The reason is that the nanofiller probably play the double role of reinforcer and the filler at this amount. This means that up to a certain phr it was as a reinforcer and henceforth it only was the filler.

Table 6 shows hardness and resilience of nanocomposites. It is obvious that as the content of nanosilica increases the hardness is kept rather constant compared to the reference value. This observation is interesting. The higher resilience means more energy is returned, or in other words, less heat remains in the compound, which increases the tire life. Based on Table 6, the compound with $3 \mathrm{phr}$ nanofiller is more desirable. It is obvious that a product with lower weight, which satisfies standard conditions, is one of the major purposes of the rubber industry. Therefore, as shown in Fig. 2 by increasing nanosilica loading, specific gravity (SPGR) value for nanocomposite series is relatively constant compared to the reference value. This result is desirable.

Table 5. Tensile properties of nanocomposites series

\begin{tabular}{|c|c|c|c|}
\hline $\begin{array}{c}\text { Nano- } \\
\text { silica, phr }\end{array}$ & $\begin{array}{c}\text { Tens.ST, } \\
\mathrm{MPa}\end{array}$ & $\begin{array}{c}\text { Elongation, } \\
\%\end{array}$ & $\begin{array}{c}\text { Modulus, MPa } \\
300 \%\end{array}$ \\
\hline 0 & 14.20 & 440 & 9.80 \\
\hline 1 & 15.60 & 485 & 9.60 \\
\hline 3 & 15.90 & 423 & 11.70 \\
\hline 5 & 13.60 & 457 & 9.0 \\
\hline
\end{tabular}

Table 6. Hardness and resilience of nanocomposites series

\begin{tabular}{|c|c|c|}
\hline Nano-silica, phr & Hardness, shore A & Resilience, $\%$ \\
\hline 0 & 57 & 28 \\
\hline 1 & 57 & 26 \\
\hline 3 & 58 & 27 \\
\hline 5 & 58 & 25 \\
\hline
\end{tabular}

A lifetime of rubber compound directly depends on abrasion resistance. In rubber industry, the abrasion resistance is the resistance of a cured rubber compound to erode, when it is in dynamic contact with an abrasive 
surface. ${ }^{33}$ This property is reported as weight loss percent. The results of this test are illustrated in Table 7. Based on these data, the compound with $3 \mathrm{phr}$ nanofiller has the least value of the weight loss, which makes it an acceptable option.

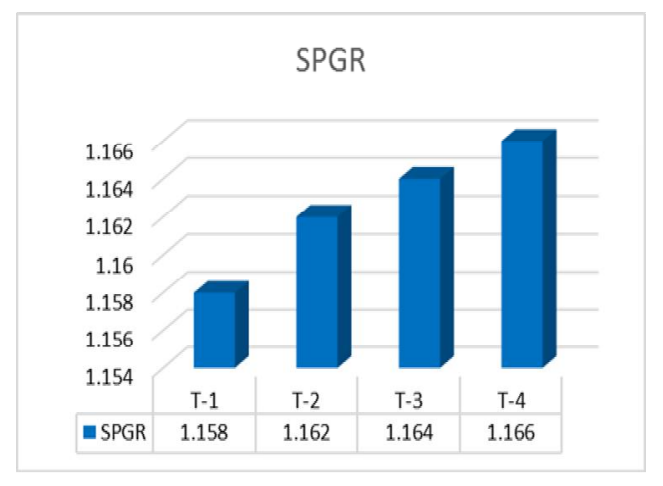

Fig. 2. SPGR of nanocomposite series

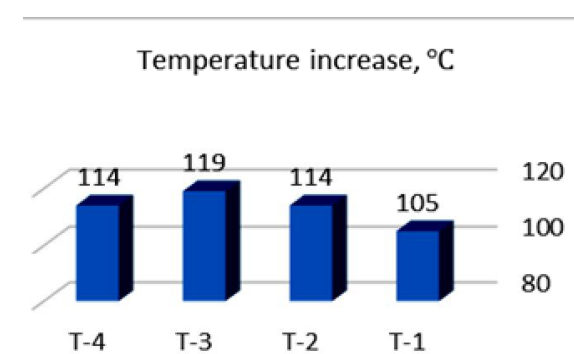

a)
Generally, dispersion test is performed to determine filler distribution in a rubber matrix. In this research, the dispersion of carbon black (CB) was studied. Table 7 shows the dispersion of this filler in the nanocomposites. The gradation of device is in the range of 0 and 10 . As the value of the device output is closer to 10 , it denotes a better dispersion of the filler. It can be seen that the dispersion of carbon black is improved when the silica nanoparticles are added. Maximum improvement in the dispersion is observed for nanocomposite with $1 \mathrm{phr}$ nanofiller and the value is 7.62 .

Table 7. Abrasion resistance and dispersion of carbon black in nanocomposite series

\begin{tabular}{|c|c|c|c|c|}
\hline Nano-silica, phr & 0 & 1 & 3 & 5 \\
\hline $\begin{array}{c}\text { Abrasion resistance, weight } \\
\text { loss percent after 172 round }\end{array}$ & 24 & 26 & 20 & 20.5 \\
\hline Dispersion of carbon black, $\bar{X}$ & 6.53 & 7.62 & 7.47 & 7.58 \\
\hline
\end{tabular}

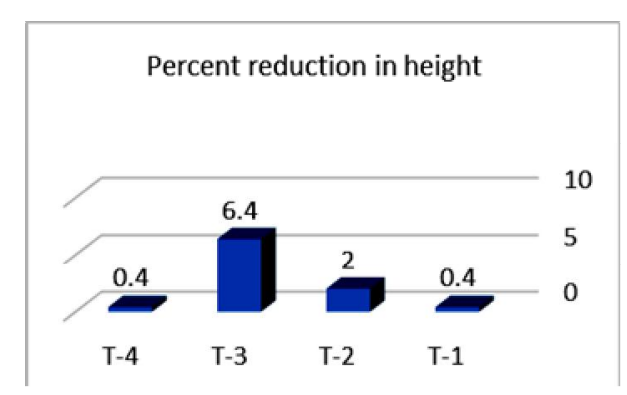

b)

Fig. 3. Heat buildup results of nanocomposite series: temperature increase (a) and percent reduction in height (b)

The phenomenon of residual heat (waste energy) in a piece of rubber is the main cause of heat generation and therefore weakens the properties of the cured compound. ${ }^{34}$ Fig. 3 shows the results of HBU test of nanocomposites series. The device measures the temperature increase and height reduction percentage of the compounds. Therefore, as the amount of these two parameters is lower, the accumulation of heat in the compound is less. According to the results, minimum temperature increase (Fig. 3a) and height reduction percentage (Fig. 3b) are for compound with $5 \mathrm{phr}$ nanofiller. These values are $387 \mathrm{~K}\left(114{ }^{\circ} \mathrm{C}\right)$ and $0.4 \%$, respectively.

Flex cracking resistance is defined as the resistance of a rubber product to initiation of crack formation and its growth due to dynamic bending stresses. The number of cycles required to tear the sample is considered as a measure of cracking resistance. ${ }^{33}$ Two samples of each compound (i.e., T-1, T-2, T-3 and T-4) were prepared; the first sample was without a crack and another one with a crack of $2 \mathrm{~mm}$ thickness. The results of this test are reported in Table 8. It can be observed that $1 \mathrm{phr}$ nanocomposite (i.e., T-2) is more appropriate because the sample without crack remained without any changes up to the end of the test. Moreover, the growth of the crack thickness in the sample with crack was less than for other compounds. As one can see from Table 8, the sample with the crack of the T-1 compound was not torn up to $60000 \mathrm{rpm}$.

Table 8. Flex cracking resistance of nanocomposites series

\begin{tabular}{|c|c|c|c|c|c|c|c|c|}
\hline Composite name & $\begin{array}{c}\mathrm{T}-1 \\
\# 1\end{array}$ & $\begin{array}{c}\mathrm{T}-1 \\
\# 2\end{array}$ & $\begin{array}{c}\mathrm{T}-2 \\
\# 1\end{array}$ & $\begin{array}{c}\mathrm{T}-2 \\
\# 2\end{array}$ & $\begin{array}{c}\mathrm{T}-3 \\
\# 1\end{array}$ & $\begin{array}{c}\mathrm{T}-3 \\
\# 2\end{array}$ & $\begin{array}{c}\mathrm{T}-4 \\
\# 1\end{array}$ & $\begin{array}{c}\mathrm{T}-4 \\
\# 2\end{array}$ \\
\hline 1 & 2 & 3 & 4 & 5 & 6 & 7 & 8 & 9 \\
\hline Temperature chamber, K & 310 & 310 & 310 & 310 & 310 & 310 & 310 & 310 \\
\hline Exposure time in the chamber, min & 10 & 10 & 10 & 10 & 10 & 10 & 10 & 10 \\
\hline Initial crack length $/ \mathrm{mm}$ & 0 & 2 & 0 & 2 & 0 & 2 & 0 & 2 \\
\hline
\end{tabular}


Continuation of Table 8

\begin{tabular}{|c|c|c|c|c|c|c|c|c|c|}
\hline \multicolumn{2}{|c|}{1} & 2 & 3 & 4 & 5 & 6 & 7 & 8 & 9 \\
\hline \multirow{8}{*}{ Crack thickness, mm } & $5000 /$ round & 0 & 6 & 0 & 9 & 0 & 10 & 0 & 8 \\
\hline & 10000 & 0 & 10 & 0 & 16 & 0 & 15 & 0 & 11 \\
\hline & 15000 & 0 & 12 & 0 & 20 & 3 & 20 & 0 & 15 \\
\hline & 20000 & 0 & 15 & 0 & 22 & 4 & 23 & 0 & 17 \\
\hline & 30000 & 0 & 20 & 0 & tear & 6 & tear & 2 & 23 \\
\hline & 40000 & 0 & 20 & 0 & tear & 13 & tear & 8 & tear \\
\hline & 50000 & 0 & 20 & 0 & tear & 20 & tear & 14 & tear \\
\hline & 60000 & 0 & 20 & 0 & tear & 22 & tear & 18 & tear \\
\hline
\end{tabular}

Table 9. Ageing mechanical properties of nanocomposite series

\begin{tabular}{|c|c|c|c|c|}
\hline Nano-silica, phr & 0 & 1 & 3 & 5 \\
\hline SPGR & 1.157 & 1.159 & 1.161 & 1.164 \\
\hline Ten.ST, MPa & 14.70 & 15.30 & 15.20 & 16.10 \\
\hline Elongation, \% & 377 & 383 & 392 & 445 \\
\hline Modulus, MPa 300\% & 12.44 & 12.70 & 12.90 & 12.30 \\
\hline HD, shoreA & 61 & 61 & 60 & 61 \\
\hline Resilience, \% & 30 & 30 & 30 & 29 \\
\hline
\end{tabular}

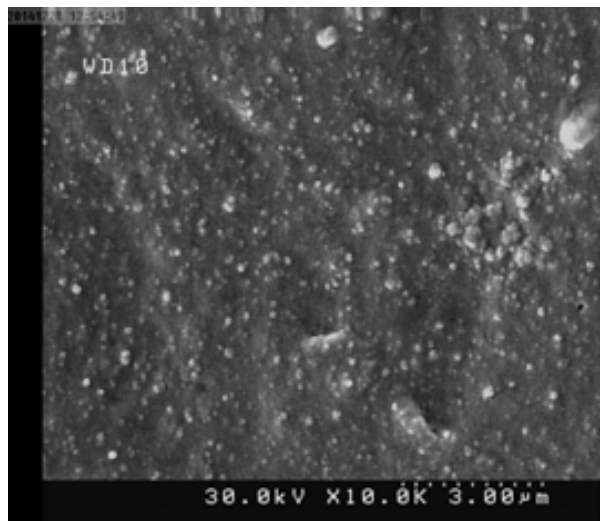

Fig. 4. Fe-SEM of nanocomposite with 3 phr nanofiller

The ability of samples to maintain their physical properties was also evaluated by ageing tests [33]. In this respect, compound series were placed in the oven for $24 \mathrm{~h}$ at $373 \mathrm{~K}$ and then ring tests (mechanical properties) were performed on them. Table 9 gives the results. After comparing these properties and the results of the initial properties without ageing (Fig. 2, Tables 5-6), it was concluded that the compound with $3 \mathrm{phr}$ nanofiller would be a good choice as changes in its properties were lesser than in other compounds.

From the results presented, it can be concluded that the compound containing $3 \mathrm{phr}$ hydrophilic silica nanoparticles is an appropriate option in the nanocomposites series. Improving the properties of this compound can be attributed to the homogenous dispersion of silica nanoparticles in the polymer matrix. This result can be proved by observing Fe-SEM image of the nanocomposite with $3 \mathrm{phr}$ nanofiller (Fig. 4). The bright dots in the image represent silica nanoparticles. As can be seen in some parts, there are a few aggregates, but the particles dispersion is homogenous, totally.

\section{Conclusions}

In this study, silica nanoparticles were used as a reinforcement filler to improve properties of tread compound used in automotive tyres. Nanocomposites were prepared using banbury mixer at the concentration of 1,3 and $5 \mathrm{phr}$ silica nanoparticles. Due to the specific characteristics of the tread compound and the results of tests, it can be concluded that the compound containing $3 \mathrm{phr}$ hydrophilic silica nanoparticles is more suitable, due to its higher tensile strength, modulus, resilience, and abrasion resistance, better cure conditions, higher ability to maintain its properties and homogenous dispersion of nanofiller in the polymer matrix, in comparison with other compounds. Homogeneous dispersion of nanoparticles increases the surface area between rubber macromolecules and nanofiller particles, and thus makes stronger interactions between them, that leads to the formation of strong cross-linked network in the curing reaction as well as strengthens the polymer and filler network. It is also observed that due to better performance of nanofiller than conventional fillers, even low levels of these fillers can provide a significant improvement in the properties of the tyre, which in economic terms is more affordable.

\section{Acknowledgments}

The authors would like to express their appreciation to the Barez Tyre Co., Kerman, Iran in allowing them to carry out the tests in their research laboratory.

\section{References}

[1] Rajarao, R.; Farzana, R., Khanna R.; Sahajwalla, V. Synthesis of $\mathrm{SiC} / \mathrm{Si}_{3} \mathrm{~N}_{4}$ Nanocomposite by Using Automotive Waste Tyres as 
Resource. J. Ind. Eng. Chem. 2015, 29, 35-38.

https://doi.org/10.1016/j.jiec.2015.04.006

[2] Tullo, A. Chemical Companies Hope Their Innovations Can Improve the Environmental Performance of Tires without Sacrificing Safety and Durability. Chem. Eng. News. 2009, 87, 10. https://doi.org/10.1021/cen-v087n046.p010

[3] Marković, G.; Radovanović, B.; Marinović-Cincović, M.; Budinski-Simendić, J. The Effect of Accelerators on Curing Characteristics and Properties of Natural Rubber/Chlorosulphonated Polyethylene Rubber Blend. Mater. Manuf. Process. 2009, 24, 1224-1228. https://doi.org/10.1080/10426910902967087

[4] Paul, D.; Robeson, L. Polymer Nanotechnology:

Nanocomposites. Polymer. 2008, 49, 3187-3204.

https://doi.org/10.1016/j.polymer.2008.04.017

[5] Chawla, V.; Prakash, S.; Sidhu B. State of the Art: Applications of Mechanically Alloyed Nanomaterials - A Review. Mater. Manuf. Process. 2007, 22, 469-473.

https://doi.org/10.1080/10426910701235900

[6] Abdul Salim, Z.; Hassan, A.; Ismail, H. A Review on Hybrid

Fillers in Rubber Composites. Polym. Plast. Technol. Eng. 2018, 57, 523-539. https://doi.org/10.1080/03602559.2017.1329432

[7] Bagheri, H.; Hashemipour, H.; Ghader, S. Population Balance Modeling: Application in Nanoparticle Formation Through Rapid Expansion of Supercritical Solution. Comput. Part. Mech. 2019, 6, 721-737. https://doi.org/10.1007/s40571-019-00257-w

[8] Bagheri, H.; Hashemipour, H.; Mirzaie, M. Investigation on Hydrodynamic and Formation of Nano Particle by RESS Process: The Numerical Study. J. Mol. Liq. 2019, 281, 490-505.

https://doi.org/10.1016/j.molliq.2019.02.108

[9] Bagheri, H.; Mansoori, G.; Hashemipour, H. A Novel Approach to Predict Drugs Solubility in Supercritical Solvents for RESS Process Using Various Cubic Eos-Mixing Rule. J. Mol. Liq. 2018, 261, 174-188. https://doi.org/10.1016/j.molliq.2018.03.081 [10] Rubber Technologist's Handbook, Vol. 2; De, S.; Naskar, K.; White, J., Eds.; Smithers Rapra Technology: Shawbury, UK, 2009. [11] Ahn, S.; Kim, S.; Kim, B. et al. Mechanical Properties of Silica Nanoparticle Reinforced Poly(ethylene2,6-naphthalate). Macromol. Res., 2004, 12, 293-302. https://doi.org/10.1007/BF03218403

[12] Ekengwu, I.; Utu, O.; Okafor, C. Nanotechnology in Automotive Industry: The Potential of Graphene. Iconic Res. Eng. J., 2019, 3, 31-37.

https://irejournals.com/formatedpaper/1701322.pdf [13] Vishvanathperumal, S.; Anand, G. Effect of Nanosilica and Crosslinking System on the Mechanical Properties and Swelling Resistance of EPDM/SBR Nanocomposites with and without TESPT. Silicon. 2020. https://doi.org/10.1007/s12633-020-00792-9 [14] White, J.; Kim, K. Thermoplastic and Rubber Compounds. Technology and Physical Chemistry; Hanser Publications: Ohio, 2012.

[15] Bhattacharya, M.; Bhowmick A. Synergy in Carbon BlackFilled Natural Rubber Nanocomposites. Part I: Mechanical, Dynamic Mechanical Properties, and Morphology. J. Mater. Sci. 2010, 45, 6126-6138. https://doi.org/10.1007/s10853-010-4699-6 [16] Ten Brinke, A. Silica Reinforced Tyre Rubbers. PhD thesis, University of Twente, the Netherlands, 2002.

[17] Kumbul, A.; Gokturk, E.; Sahmetlioglu, E. Synthesis, Characterization, Thermal Stability and Electrochemical Properties of Ortho-Imine-Functionalized Oligophenol via Enzymatic Oxidative Polycondensation. J. Polym. Res. 2016, 23, 52. https://doi.org/10.1007/s10965-016-0953-1

[18] Pal, K.; Rajasekar, R.; Kang, D. et al. Effect of Fillers on Natural Rubber/High Styrene Rubber Blends with Nano Silica: Morphology and Wear. Mater. Des. 2010, 31, 677-686. https://doi.org/10.1016/j.matdes.2009.08.014

[19] Kaewsakul, W. Silica-Reinforced Natural Rubber for Low Rolling Resistance, Energy-Saving Tires: Aspects of Mixing, Formulation and Compatibilization. PhD thesis, University of Twente, the Netherlands, 2013.

[20] Xia, L.; Song, J.; Wang, H.; Kan, Z. Silica Nanoparticles Reinforced Natural Rubber Latex Composites: The Effects of Silica Dimension and Polydispersity on Performance. J. Appl. Polym. Sci., 2019, 136, 47449. https://doi.org/10.1002/app.47449

[21] Tancharernrat, T.; Rempel, G.; Prasassarakich, P. Preparation of Styrene Butadiene Copolymer-Silica Nanocomposites via Differential Microemulsion Polymerization and NR/SBR-SiO Membranes for Pervaporation of Water-Ethanol Mixtures. Chem. Eng. J. 2014, 258, 290-300.

https://doi.org/10.1016/j.cej.2014.05.151

[22] Rubber Nanocomposites: Preparation, Properties, and Applications; Thomas, S., Stephen, R., Eds.; John Wiley \& Sons, 2010. https://doi.org/10.1002/9780470823477

[23] Park, S.; Jin, S.; Kaang, S. Influence of Thermal Treatment of Nano-Scaled Silica on Interfacial Adhesion Properties of the Silica/Rubber Compounding. Mater. Sci. Eng. A. 2005, 398, $137-$ 141. https://doi.org/10.1016/j.msea.2005.03.012

[24] Chen, Y.; Peng, Z.; Kong, L. et al. Natural Rubber

Nanocomposite Reinforced with Nano Silica. Polym. Eng. Sci. 2008, 48, 1674-1677. https://doi.org/10.1002/pen.20997

[25] Mathew, L.; Narayanankutty, S. Nanosilica as Dry Bonding System Component and as Reinforcement in Short Nylon-6 Fiber/Natural Rubber Composite. J. Appl. Polym. Sci. 2009, 112, 2203-2212. https://doi.org/10.1002/app.29718

[26] Meera, A.; Said, S.; Grohens, Y. et al. Tensile Stress Relaxation Studies of $\mathrm{TiO}_{2}$ and Nanosilica Filled Natural Rubber Composites. Ind. Eng. Chem. Res., 2009, 48, 3410-3416. https://doi.org/10.1021/ie801494s

[27] Chayan, D.; Kapgate Bharat, P. Preparation and Studies of Nitrile Rubber Nanocomposites with Silane Modified Silica Nanoparticles. Res. J. Recent Sci. 2012, 1, 357-360.

$\mathrm{http} / / / \mathrm{www}$.isca.in/rjrs/archive/v1/iISC-2011/62.ISCA-ISC-201111MatS-05.pdf

[28] Yusof, N.; Noguchi, K.; Fukuhara, L. et al. Preparation and Properties of Natural Rubber with Filler Nanomatrix Structure. Colloid Polym. Sci. 2015, 293, 2249-2256.

https://doi.org/10.1007/s00396-015-3615-7

[29] Ahmed, J.; Al-Maamori, M.; Ali, H. Effect of Nano Silica on the Mechanical Properties of Styrene-Butadiene Rubber (SBR)

Composite. Int. J. Mater. Sci. Appl., 2015, 4, 15-20.

https://doi.org/10.11648/j.ijmsa.s.2015040201.14

[30] Advanced Rubber Composites; Heinrich, G., Ed.; Springer

Science \& Business Media, 2011. https://doi.org/10.1007/978-3642-19504-4

[31] Dileep, P.; Narayanankutty, S. Styrenated Phenol Modified Nanosilica for Improved Thermo-Oxidative and Mechanical Properties of Natural Rubber. Polym. Test., 2020, 82, 106302. https://doi.org/10.1016/j.polymertesting.2019.106302

[32] Dileep, P.; Narayanankutty, S. A Novel Method for Preparation of Nanosilica from Bamboo Leaves and Its Green Modification as a Multi-Functional Additive in Styrene Butadiene Rubber. Mater.

Today Commun. 2020, 24, 100957.

https://doi.org/10.1016/j.mtcomm.2020.100957

[33] Hawleyown, S. Physical Testing of Rubber-Third Edition: By R. P. Brown. Chapman and Hall, London, 1996. 352 pp. ISBN 0412-60890-1. Polym. Test. 1996, 5, 501-502.

https://doi.org/10.1016/0142-9418(96)00024-4

[34] Ramarad, S.; Khalid, M.; Ratnam, C. et al. Waste Tire Rubber in Polymer Blends: a Review on the Evolution, Properties and 
Future. Prog. Mater. Sci. 2015, 72, 100-140.

https://doi.org/10.1016/j.pmatsci.2015.02.004

Received: March 25, 2020/Revised: August 03, 2020 / Accepted: December 12, 2020

\section{ВПЛИВ НАНОЧАСТИНОК ГІДРОФІЛЬНОГО КРЕМНЕЗЕМУ НА МОРФОЛОГІЮ ТА МЕХАНІЧНІ ВЛАСТИВОСТІ КОМПОНЕНТІВ ТИПОВИХ ШИН}

Анотація. Вивчено вплив наночастинок гідрофільного кремнезему як нанонаповнювача на властивості протектора шин. Методом змішування розплаву виготовлено чотири сполуки, з кількістю нанонаповнювача 0, 1, 3 та 5 phr (частин наповнювача на сто частин гуми). Визначено фізико-механічні властивості одержаних сполук. За допомогою скануючої електронної мікроскопії з польовою емісією (Fe-SEM) встановлено структуру та морфологію поверхні. Доведено, щзо зразок, який містить 3 phr нанонаповнювача, має найкращі властивості. Це зумовлене вищою взаємодією між нанонаповнювачем та полімерними макромолекулами, що спричиняе краму дисперсію наночастинок у полімерній матриці.

Ключові слова: наповнювач гуми, механічні властивості, гідрофільні наночастинки кремнезему, метод змішування розплаву, стійкість до стирання. 